\title{
Kosowo - koniec Europy?
}

GENEZA ZAANGAŻOWANIA - UE WOBEC KRYZYSU WEWNĘTRZNEGO

TEsienią 1997 RoKU doszło do kryzysu wewnętrznego w Kosowie. Albańczycy, stanowiący 90\% ludności, wsparli Armię Wyzwolenia Kosowa, która podjęła akcję zmierzającą do oderwania Kosowa od Federacyjnej Republiki Jugosławii. Władze Serbii wykorzystały milicję i wojsko do przeprowadzenia akcji pacyfikacyjnych. Wiosną $1998 \mathrm{r}$. konflikt zaostrzył się. Rada Unii Europejskiej uzgodniła wówczas trzy wspólne stanowiska o wprowadzeniu restrykcji ekonomicznych wobec Federacyjnej Republiki Jugosławii, dotyczące kolejno: zamrożenia aktywów rządu jugosłowiańskiego za granicą ${ }^{1}$, zakazu nowych inwestycji w Serbii ${ }^{2}$, zawieszenia komunikacji lotniczej między FR Jugosławii a Wspólnotą Europejską3. W sierpniu Rada podjęła decyzję o zakazie eksportu broni do państw byłej Jugosławii ${ }^{4}$. W grudniu sformułowano wspólne stanowisko dotyczące środków restrykcyjnych wobec osób działających na terytorium FR Jugosławii przeciwko niezależnym mediom $^{5}$ oraz decyzję o powołaniu specjalnego przedstawiciela UE dla FR Jugosławii ${ }^{6}$.

${ }^{1}$ Wspólne stanowisko 1998/326/WPZiB z dnia 7 maja 1998 r. dotyczace funduszy posiadanych za granica przez rzady Federalnej Republiki Jugostawii i Serbii, Dz. U. L 143 z 14.5.1998.

${ }^{2}$ 98/374/PESC: Position commune du 8 juin 1998 définie par le Conseil sur la base de l'article J.2 du traité sur l'Union européenne, concernant l'interdiction de nouveaux investissements en Serbie, JO L 165 du 10.6.1998.

${ }^{3}$ 98/426/PESC: Position commune du 29 juin 1998 définie par le Conseil sur la base de l'article J.2 du traité sur l'Union européenne concernant l'interdiction des vols effectués par des transporteurs yougoslaves entre la République fédérale de Yougoslavie et la Communauté européenne, JO L 190 du 4.7.1998.

${ }^{4}$ Decyzja Rady z dnia 10 sierpnia 1998 r. zmieniająca wspólne stanowisko 96/184/ WPZiB określone przez Radę na podstawie art. J.2 Traktatu o Unii Europejskiej dotyczące wywozu broni do byłej Jugosławii, Dz.U. L 225 z 12.8.1998.

${ }^{5}$ Decyzja Rady z dnia 10 sierpnia 1998 r. zmieniająca wspólne stanowisko 96/184/ WPZiB określone przez Radę na podstawie art. J.2 Traktatu o Unii Europejskiej dotyczące wywozu broni do byłej Jugosławii, Dz. U. L. 225 z 12.8.1998.

${ }^{6}$ 98/741/PESC: Décision du Conseil du 28 décembre 1998 concernant la prorogation de l'action commune 98/375/PESC relative à la désignation d'un représentant 
24 marca 1999 r. rozpoczęła się operacja NATO pod nazwą „Allied Force”. 30 marca Rada Unii Europejskiej podjęła decyzję o wspólnym działaniu w sprawie kryzysu kosowskiego ${ }^{7}$. Miesiąc później Rada sformułowała wspólne stanowisko ustanawiające zakaz sprzedaży ropy naftowej oraz produktów pochodnych do państw FR Jugosławii, do którego przyłączyły się państwa stowarzyszone z UE z Europy Środkowej, Cypr oraz państwa EFTA - członkowie EOG.

Rada Europejska z Kolonii z czerwca 1999 r. podkreśliła wolę UE odegrania wiodącej roli w odbudowie Kosowa. Natychmiast po zakończeniu konfliktu Komisja Europejska przekazała 378 mln euro w ramach pomocy humanitarnej na sytuacje wyjątkowe. Wysłała również na miejsce zespół mający za zadanie wprowadzać w życie pierwsze programy odbudowy, łączące działania humanitarne z programami długoterminowego rozwoju wdrażanymi przez Europejską Agencję Odbudowy, a także udzieliła 65 mln euro w ramach wyjątkowej pomocy finansowej dla skonsolidowanego budżetu Kosowa. Zobowiązała się do uczestnictwa w tymczasowej administracji ONZ (UNMIK), ustanawiając filar IV ${ }^{8}$.

10 czerwca 1999 r. wypracowano porozumienie o wprowadzeniu do Kosowa sił pokojowych KFOR ${ }^{9}$. W 2001 roku UNMIK zorganizowała w Kosowie wybory. Rok później powołane zostały Tymczasowe Instytucje Autonomiczne (ang. Provisional Institutions of Self-Government - PISG), traktowane przez kosowskich Albańczyków jako jedyne posiadające legitymację organa władzy. Zarówno brak postępów w kwestii przyszłego statusu Kosowa, jak i brak uregulowań co do długości trwania mandatu UNMIK, były źródłem narastających frustracji ${ }^{10}$. W połowie $2002 \mathrm{r}$. zainicjowany został przez Specjalnego

spécial de l'Union européenne pour la République fédérale de Yougoslavie, JO L 358 du 31.12.1998.

7 Uściślono mandat powołanego 5 października 1998 r. specjalnego wysłannika, którego zadaniem miało być obserwowanie sytuacji w rejonie konfliktu.

${ }^{8}$ IV filar UNMIK, zwany „unijnym”, objął odbudowę i rozwój ekonomiczny.

${ }^{9}$ Kosowo było od 1999 r. zarządzane przez Misję Tymczasowej Administracji Organizacji Narodów Zjednoczonych w Kosowie (ang. United Nations Interim Administration in Kosovo - UNMIK) i Specjalnego Przedstawiciela Sekretarza Generalnego ONZ. Kwestiami administracji publicznej oraz policji i sądownictwa zajmowała się ONZ. OBWE nadzorowała procesy demokratyzacji i budowy instytucji, natomiast o odbudowę i rozwój gospodarczy zabiega UE. Pokój zapewniały siły ONZ - KFOR - składające się z kontyngentów NATO. Odpowiedzialność była jednak stopniowo cedowana na lokalne władze.

${ }^{10}$ Władze w Belgradzie postrzegały każde działanie UNMIK mające na celu powołanie stabilnego systemu instytucji w Kosowie jako jednostronny, nieuprawniony krok 
Przedstawiciela Sekretarza Generalnego ONZ, Michaela Steinera, proces określany jako „standardy przed statusem”.

W kolejnych miesiącach wspólne planowanie wdrażania standardów przyczyniło się do odbudowania chylących się ku rozłamowi relacji PISG-UNMIK. Rada Bezpieczeństwa ONZ wsparła plan Standardy dla Kosowa ${ }^{11}$. Od maja 2004 roku starania PISG, by wypełnić wskazane normy, były oceniane w kwartalnych raportach UNMIK kierowanych do Rady Bezpieczeństwa ONZ. PISG cieszyły się jednak zaufaniem albańskiej społeczności Kosowa jedynie w ograniczonym zakresie $^{12}$.

W roku 2004 został powołany nowy rząd, ONZ zachowała jednak decydujący głos w najważniejszych decyzjach legislacyjnych. 20 grudnia 2005 r. utworzone zostały ministerstwa spraw wewnętrznych i sprawiedliwości w rządzie Kosowa. Zdania w dyskusji o przyszłym statusie Kosowa były podzielone głównie wzdłuż linii różnic etnicznych. Albańczycy opowiadali się za niepodległością, Serbowie - przeciwko.

24 października 2005 roku Rada Bezpieczeństwa ONZ otworzyła negocjacje nad przyszłym statusem prowincji. Po dziewięciu rundach rozmów Kosowo i Serbia nie wypracowały satysfakcjonującego rozwiązania. Bez rozstrzygnięcia pozostawała kwestia powrotu do domów i restytucji mienia Serbów. W sierpniu 2006 r. rząd Kosowa i UNMIK sporządziły wstępny plan integracji prowincji z UE, przy założeniu uzyskania przez nią niepodległości. Dokument zatytułowany „Europejski Plan Działań Kosowa” przedłożono Komisji Europejskiej.

\section{Partnerstwo Europejskie i KonkluzJe PrezydencJi}

UNIA EURopesSKa odgrywała fundamentalną rolę w odbudowie Kosowa po konflikcie, szczególnie przez uczestnictwo w IV filarze UNMIK. Była najważniejszym dawcą pomocy. Przedstawiciele UE byli zgodni w potępianiu aktów przemocy, popieraniu decentralizacji, deklarowa-

w kierunku ogłoszenia i uznania niepodległości Kosowa. Collapse in Kosovo, IGC Europe Report No 155,22 April 2004.

${ }^{11}$ Przygotowany przez Grupę Kontaktową, obejmował on osiem grup owych standardów: funkcjonowanie instytucji demokratycznych, rządy prawa, swobodę przemieszczania się i powrotu do miejsca zamieszkania, prawa wspólnot, ekonomię, prawa własności, dialog między PISG i władzami w Belgradzie, budowanie Korpusu Ochrony Kosowa jako cywilnej jednostki reagowania w sytuacjach kryzysowych.

${ }^{12}$ Collapse in Kosovo, op. cit. 
niu, że jakikolwiek byłby przyszły status Kosowa, należy ono do Europy.

W konkluzjach Prezydencji ze szczytu Rady Europejskiej 16 i 17 października 2003 r. potwierdzono, że dialog między Belgradem a Prištiną w kwestiach praktycznych jest punktem przełomowym strategii międzynarodowej Wspólnoty „standardy przed statusem”, opartej na rezolucji nr 1244 Rady Bezpieczeństwa ONZ. Stanowi on również istotny krok ku normalizacji sytuacji w Kosowie oraz w zbliżaniu się do standardów europejskich w ramach procesu stabilizacji i stowarzyszenia ${ }^{13}$. Rada Europejska z zadowoleniem przyjęła zainicjowanie tego dialogu w Wiedniu. Podkreśliła znaczenie powołania technicznych grup roboczych w sprawach energii, transportu i komunikacji, osób powracających i zaginionych podstawach wielonarodowych. Wyraziła wsparcie dla wysiłków, jakie czynił w tym kierunku Harri Holkeri, specjalny przedstawiciel Sekretarza Generalnego ONZ ${ }^{14}$. „Partnerstwo europejskie dla Kosowa” 15 przyjęte w czerwcu 2004 r. przedstawia działania, mające zapewnić wdrożenie norm ${ }^{16}$.

W konkluzjach Prezydencji z 25-26 marca 2004 roku potępiono przemoc na tle etnicznym, ataki na siły KFOR oraz stanowiska i personel UNMIK, a także akty niszczenia prywatnego mienia oraz obiektów kulturalnego i religijnego dziedzictwa. Rada Europejska podkreśliła potrzebę współpracy politycznych liderów w Kosowie z UNMIK i KFOR w celu zapewnienia fizycznego bezpieczeństwa i pełnej ochrony praw wszelkich wspólnot w Kosowie ${ }^{17}$. Serbia zostałaby zaproszona

${ }^{13}$ Mechanizm monitoringu procesu stabilizacji i stowarzyszenia (ang. Stabilisation and Association Process Tracking Mechanism - STM) umożliwia dyskutowanie na forum postępów Kosowa we wdrażaniu partnerstwa europejskiego. Komisja zamierza monitorować postępy we wprowadzaniu norm ONZ, by wzmocnić ogólną świadomość UE na temat sytuacji w Kosowie. Planuje ona rozwijać techniczne grupy sektorowe w ramach STM w celu pogłębienia dyskusji ekspertów z ministerstw i ze służb Komisji.

${ }^{14}$ Spotkanie Rady Europejskiej w Brukseli, Wnioski Prezydencji, 16-17 października 2003 r. , Wnioski Prezydencji, Urząd Komitetu Integracji Europejskiej, http://www. ukie.gov.pl, 10.02.2010.

${ }^{15}$ Decyzja Rady z dnia 14 czerwca 2004 r. w sprawie zasad, priorytetów i warunków zawartych $w$ Partnerstwie Europejskim z Serbią i Czarnogórą, w tym z Kosowem zgodnie z jego statusem ustanowionym przez rezolucję $n r 1244$ Rady Bezpieczeństwa Narodów Zjednoczonych 10 czerwca 1999 r., Dz.U. L 227 z 26.6.2004.

${ }^{16}$ Odpowiedzią władz Kosowa był plan działania, który określał środki wdrożenia priorytetowych norm oraz działania późniejsze; szacował koszty dla rządu Kosowa oraz określał pomoc wymaganą dla całościowej oceny norm oraz, w dłuższym horyzoncie czasowym, europejski program zbliżania norm.

${ }_{17}$ Brussels European Council 25 and 26 march 2004, Presidency Conclusions, Brussels, 19 may 2004, 9048/04. 
do udziału w planie i kontynuowania proeuropejskiego trendu. Uzyskałaby przy tym status państwa kandydującego do Unii Europejskiej, dołączając do Chorwacji i Macedonii ${ }^{18}$.

Konkluzje Prezydencji z 17-18 czerwca 2004 r. wyrażały pozytywną ocenę Rady Europejskiej oświadczenia Sekretarza Generalnego ONZ, że zamierza on mianować Sorena Jessena Petersena swoim specjalnym przedstawicielem dla Kosowa i szefem misji UNMIK. Zapowiedziano, iż UE będzie ściśle współpracować z nowym specjalnym przedstawicielem Sekretarza Generalnego i intensywnie wspierać jego działania opierające się na wprowadzaniu w życie rezolucji nr 1244 Rady Bezpieczeństwa i zmierzające do zapewniania, by Kosowo stało się rzeczywiście wieloetniczne ${ }^{19}$.

W konkluzjach Rady ds. Ogólnych z 21-22 lutego 2005 roku zapisano: „Rada podkreśliła również, że Kosowo nie powróci do sytuacji sprzed 1999 r. Jego przyszłość można sobie wyobrażać jedynie jako państwo wieloetniczne i demokratyczne, które zapewnia skuteczną ochronę mniejszości, zabezpieczenie dziedzictwa kulturowego i religijnego wszystkich jego społeczności oraz poszanowanie praw uchodźców i wysiedleńców do powrotu, przyczyniając się do stabilizacji regionu i przestrzegania wartości i norm UE”. Rada ds. Ogólnych i Stosunków Zewnętrznych zwróciła się do Komisji Europejskiej, Wysokiego Przedstawiciela/Sekretarza Generalnego oraz do Prezydencji o zbadanie wraz z przedstawicielami ONZ i innych istotnych stron, jaki mógłby być przyszły wkład Unii Europejskiej w działania wspólnoty międzynarodowej w Kosowie przy wprowadzaniu w życie rezolucji $\mathrm{nr}$ 1244, w ogólną ocenę wdrożenia norm oraz w późniejszych fazach procesu $^{20}$.

\section{EUROPEJSKA PRZYSZEOŚĆ KOSOWA}

KolEJNYM DOKumentem DOTYCZĄCYM Kosowa był Komunikat Komisji do Rady z 20 kwietnia 2005 r. „Europejska przyszłość Kosowa”. Wskazano w nim, iż „Perspektywa europejska Bałkanów Zachodnich, potwierdzona w deklaracji z Salonik z czerwca 2003 r., jest otwarta także dla Kosowa. W oparciu o rezolucję Rady Bezpieczeństwa ONZ nr 1244, Kosowo musi przezwyciężyć swoją izolację oraz uczestniczyć w postę-

${ }^{18}$ Ibidem.

${ }^{19}$ Rada Europejska w Brukseli 17-18 czerwca 2004, Konkluzje Prezydencji, Bruksela 18 czerwca 2004, 10679/04.

${ }^{20}$ Udział w prowadzeniu tych badań mieli wziąć przedstawiciele ONZ i innych istotnych stron. 
pach regionu na drodze do Europy" ${ }^{21}$. Komunikat koncentruje się na dziedzinach podlegających kompetencji Wspólnoty i znajdujących się w gestii Komisji. Akcentuje się w nim gospodarcze aspekty rozwoju Kosowa, rozwój instytucjonalny, wsparcie ze strony $\mathrm{WE}^{22}$ oraz kwestie regionalne. Wszystkie te czynniki wchodzą w skład szerszego kontekstu, który obejmuje kwestie bezpieczeństwa, umocowanie polityczne i pojednanie między wspólnotami ${ }^{23}$.

Opinię do Komunikatu przygotował Komitet Regionów ${ }^{24}$. Przyjął on „z zadowoleniem” wnioski przedstawione przez Komisję w komunikacie „Europejska przyszłość dla Kosowa”, a także raport w sprawie przygotowania Serbii i Czarnogóry do negocjacji Układu o Stabilizacji i Stowarzyszeniu z Unią Europejską, który kończy się pozytywnym zaleceniem w kwestii rozpoczęcia negocjacji nad stabilizacją i stowarzyszeniem pod warunkiem, że Serbia i Czarnogóra będą stale kontynuować przygotowania. Podobnie pozytywna opinia dotyczyła konkluzji Prezydencji Rady Europejskiej odbytej w Brukseli 16-17 czerwca 2005 r. i załączonej deklaracji w sprawie Kosowa ${ }^{25}$.

\section{U PROGU NIEPODLEGŁOŚCI}

W CZASIE NEGOCJACJI dotyczących przyszłego statusu uznawano, iż Kosowo może ogłosić niepodległość, ale taki akt winien zostać oprawiony w ramy, które pozwoliły Unii Europejskiej zapobiec uznaniu Kosowa na forum ONZ. Oferta „specjalnego statusu w ramach UE” nie jest uznaniem de iure suwerennego państwa, choć możemy mówić o swe-

${ }^{21}$ Europejska przyszłość dla Kosowa, Komunikat Komisji do Rady, Bruksela, dnia 20.4.2005, COM (2005) 156 wersja ostateczna.

${ }^{22}$ Kosowo miało otrzymać w latach 2005-2006 dodatkowe $114 \mathrm{mln}$. euro w ramach Pomocy wspólnotowej na odbudowę, rozwój i stabilizację (Community Assistance for Reconstruction, Development and Stabilisation - CARDS) W 2007 r. rozporządzenie dotyczące instrumentów przedakcesyjnych (IPA) zastąpiło rozporządzenie w sprawie CARDS. Rozporządzenie IPA ma za zadanie wspierać postępy regionu na drodze do przystąpienia do UE. Instrument ten zapewni elastyczność, by odpowiadać na zmieniające się potrzeby. Komisja będzie miała również do swojej dyspozycji inne instrumenty RELEX, które pozwolą właściwie reagować na rozwój sytuacji w przyszłości.

${ }^{23}$ Komunikat głosi: „Bez zapewnienia bezpieczeństwa i pojednania nie będzie napływu inwestycji, a Kosowo pozostanie zależne od zewnętrznej pomocy. Komisja chętnie przyczyni się do rozwiązywania tych problemów współpracując z innymi instytucjami UE".

${ }^{24}$ Opinia Komitetu Regionów w sprawie komunikatu Komisji dla Rady „Europejska przyszłość dla Kosowa”, Bruksela 16 listopada 2005, Dz. Urz. UE C 115/53 z 16.5.2006

${ }^{25}$ Ibidem. 
go rodzaju suwerenności funkcjonalnej, z racji wchodzenia UE w relacje z rządem i wykonywania poszczególnych polityk unijnych. Pozostawiłoby to furtkę dla ewentualnych ostatecznych rozstrzygnięć prawnych, odłożonych na czas, gdy Serbia i Kosowo stawałyby się pełnoprawnymi członkami UE.

30 listopada 2006 r. przyjęta została przez Radę Unii Europejskiej decyzja o przyznaniu Kosowu wyjątkowej pomocy finansowej Wspólnoty. Artykuł 1 dokumentu stanowił: „Wspólnota udziela Kosowu wyjątkowej pomocy finansowej w postaci dotacji w kwocie do $50 \mathrm{mln}$ euro w celu poprawy sytuacji finansowej tego regionu, wsparcia procesu tworzenia trwałych struktur ekonomiczno-fiskalnych, umożliwienia kontynuacji i umocnienia istotnych funkcji administracyjnych oraz zaspokojenia zapotrzebowania na inwestycje publiczne" ${ }^{26}$. Pomocą tą zarządzać miała Komisja przy konsultacjach ze strony Komitetu Ekonomiczno-Finansowego w sposób zgodny z porozumieniami lub uzgodnieniami przyjętymi przez MFW i władze Kosowa ${ }^{27}$. Pomoc udostępniona została na okres dwu lat, przy czym Komisja, po konsultacjach z Komitetem Ekonomiczno-Finansowym, mogła przedłużyć ten okres maksymalnie o rok $^{28}$. Środki miały być przekazywane Ministerstwu Gospodarki i Finansów należącemu do PISG lub - po określeniu przyszłego statusu Kosowa - instytucji, która wyznaczona zostanie do przejęcia zadań i obowiązków tego ministerstwa, wyłącznie na pokrycie zapotrzebowania w zakresie finansowania budżetu Kosowa ${ }^{29}$.

11 grudnia 2006 r. Rada przyjęła wspólne działanie zmieniające i przedłużające wspólne działanie 2006/304/WPZiB dotyczące utworzenia zespołu UE ds. planowania na potrzeby ewentualnej operacji zarządzania kryzysem w zakresie praworządności i w ewentualnych innych dziedzinach w Kosowie. Rada została zobowiązana do dokonania do 15 kwietnia 2007 r. oceny, czy prace Zespołu ds. Planowania dla

${ }^{26}$ Art. 1 ust. 1 Decyzji Rady z dnia 30 listopada 2006 r. o przyznaniu Kosowu wyjatkowej pomocy finansowej Wspólnoty, 2006/880/WE, Dz. Urz. UE L 339/36 z 6.12.2006 r.

${ }^{27}$ Art. 1 ust. 2 Decyzji Rady z dnia 30 listopada 2006 r. o przyznaniu Kosowu wyjatkowej pomocy finansowej Wspólnoty, 2006/880/WE, Dz. Urz. UE L 339/36 z 6.12.2006 r.

${ }^{28}$ Art. 1 ust. 3 Decyzji Rady z dnia 30 listopada 2006 r. o przyznaniu Kosowu wyjątkowej pomocy finansowej Wspólnoty, 2006/880/WE, Dz. Urz. UE L 339/36 z 6.12.2006 r.

${ }^{29}$ Art. 3 ust. 3 Decyzji Rady z dnia 30 listopada 2006 r. o przyznaniu Kosowu wyjątkowej pomocy finansowej Wspólnoty, 2006/880/WE, Dz. Urz. UE L 339/36 z 6.12.2006 r. 
Kosowa powinny być kontynuowane po 31 maja 2007 r., uwzględniając potrzebę niezakłóconego przejścia do ewentualnej operacji UE zarządzania kryzysem w Kosowie ${ }^{30}$. Datę wygaśnięcia wspólnego działania ustalono na 31 maja 2007 r. lub dzień uruchomienia operacji UE zarządzania kryzysem w zależności od tego, który z nich przypadnie wcześniej ${ }^{31} .12$ grudnia 2006 r. zapadła decyzja Komitetu Politycznego i Bezpieczeństwa przedłużająca mandat szefa zespołu UE ds. planowania w związku z ewentualną operacją UE zarządzania kryzysem w zakresie praworządności i w ewentualnych innych dziedzinach w Kosowie. Na jej mocy mandat Caspera Klynge jako szefa zespołu UE ds. planowania został przedłużony do 31 maja $2007 \mathrm{r}^{32}$.

W lutym 2007 roku zaprezentowana została „Całościowa propozycja uregulowania statusu Kosowa” M. Ahtisaariego ${ }^{33}$, której głównym założeniem było przyznanie Kosowu statusu określanego mianem „nadzorowanej niepodległości”. Analitycy wskazywali jednak, iż część państw pozostanie sceptyczna wobec ryzyka naruszenia integralności terytorialnej. To mogłoby spowodować usztywnienie stanowiska Rosji i ewentualnego jej weta wobec planu Ahtisaariego w Radzie Bezpieczeństwa ONZ. Ostrzegano jednocześnie, że brak wsparcia ze strony ONZ może zapoczątkować nowy okres konfliktów na Bałkanach, wzmacniając jednocześnie pozycję Rosji, nie tylko w regionie ${ }^{34}$.

We wrześniu 2007 roku spekulowano już odnośnie przyszłej niepodległości Kosowa ${ }^{35}$. W Unii Europejskiej coraz większe poparcie zy-

${ }^{30}$ Art. 1 ust. 6 wspólnego działania Rady 2006/918/WPZiB z dnia 11 grudnia 2006 r. zmieniającego i przedtużającego wspólne działanie 2006/304/WPZiB dotyczace utworzenia zespotu UE ds. planowania (ZPUE dla Kosowa) na potrzeby ewentualnej operacji zarządzania kryzysem $w$ zakresie praworządności i $w$ ewentualnych innych dziedzinach $w$ Kosowie, Dz. Urz. UE L 349/57 z 12.12.2006 r.

${ }^{31}$ Art. 1 ust. 7 wspólnego działania Rady 2006/918/WPZiB z dnia 11 grudnia 2006 r. zmieniającego i przedtużającego wspólne działanie 2006/304/WPZiB dotyczące utworzenia zespotu UE ds. planowania (ZPUE dla Kosowa) na potrzeby ewentualnej operacji zarządzania kryzysem $w$ zakresie praworządności $i$ w ewentualnych innych dziedzinach w Kosowie, Dz. Urz. UE L 349/57 z 12.12.2006 r.

${ }^{32}$ Decyzja Komitetu Politycznego i Bezpieczeństwa ZPUE/2/2006 z dnia 12 grudnia 2006 r. przedtużająca mandat szefa zespotu UE ds. planowania (ZPUE dla Kosowa) $w$ związku z ewentualna operacja UE zarządzania kryzysem $w$ zakresie praworządności i $w$ ewentualnych innych dziedzinach $w$ Kosowie, Dz. Urz. UE L 365/88 $\mathrm{z} 21.12 .2006 \mathrm{r}$.

${ }^{33}$ Tekst dostępny na stronie: http://www.unosek.org, 10.02.2010.

${ }^{34}$ Lack of EU Solidarity Jeopardizes Kosovo Independence, http://www.atlanticcommunity.org, 10.02.2010.

${ }_{35}$ N. K. Gvosdev, Will Kosovo End the Transatlantic Honeymoon?, http://www. atlantic-community.org, 10.02.2010. 
skiwało stanowisko akceptujące ewentualną niepodległość, gdyby zyskała ona także wsparcie w rezolucji Rady Bezpieczeństwa ONZ. Było to o tyle ważne, iż część państw europejskich miała obawy związane $\mathrm{z}$ faktem, iż Kosowo mogłoby stać się precedensem ${ }^{36}$. Powszechne było w Europie przekonanie, że rozwiązanie narzucone z zewnątrz może być trwałe o tyle, o ile uznają je i będą gotowe wprowadzić je w życie zarówno strona serbska, jak i kosowska ${ }^{37}$.

19 listopada 2007 r. przyjęte zostało wspólne działanie Rady 2007/744/WPZiB zmieniające i przedłużające wspólne działanie 2006/623/WPZiB w sprawie utworzenia zespołu UE uczestniczącego w przygotowaniach do ewentualnego ustanowienia międzynarodowego biura cywilnego w Kosowie z elementem funkcji specjalnego przedstawiciela Unii Europejskiej (Zespół przygotowawczy MBC/SPUE). 29 listopada 2007 r. Rada przyjęła wspólne działanie 2007/778/WPZiB zmieniające i przedłużające wspólne działanie 2006/304/WPZiB dotyczące utworzenia zespołu UE ds. planowania (ZPUE dla Kosowa) na potrzeby ewentualnej operacji zarządzania kryzysem w zakresie praworządności i w ewentualnych innych dziedzinach w Kosowie ${ }^{38}$.

18 grudnia 2007 r. Komitet Polityczny i Bezpieczeństwa podjął decyzję dotyczącą mianowania szefa zespołu UE ds. planowania (ZPUE dla Kosowa), którym został Roy Reeves ${ }^{39}$. 4 lutego 2008 roku przyjęty został dokument o prawnych i finansowych zasadach wysłania do Kosowa misji cywilno-wojskowej pod nazwą EULEX ${ }^{40}$. Według wstęp-

${ }^{36}$ Obawy te przynajmniej częściowo potwierdziły się, gdy w dzień ogłoszenia przez Kosowo niepodległości podobny krok został zapowiedziany ze strony Abchazji i Osetii Południowej, które poparcia dla swych dążeń zamierzały szukać w Rosji i na forum ONZ. Dzień później bojownicy czeczeńscy ogłosili jednostronny akt niepodległości, porównując swoją walkę do tej, która została stoczona w Kosowie.

${ }^{37}$ N. K. Gvosdev, op. cit.

${ }^{38}$ Dodano artykuł 13a, stanowiący, iż komórka monitorująca wydarzenia obejmuje swoim działaniem ZPUE dla Kosowa. Zmianie uległ art. 14, w którym zawarto stwierdzeniem, że Rada, biorąc pod uwagę potrzebę płynnego przejścia do ewentualnej operacji UE zarządzania kryzysem w Kosowie, do 31 stycznia 2008 r. miała ocenić, czy ZPUE dla Kosowa powinien kontynuować swoje prace po dniu 31 marca 2008 r. Uzgodniono, że wspólne działanie wygaśnie 31 marca $2008 \mathrm{r}$.

39 Art. 1 Decyzji Komitetu Politycznego i Bezpieczeństwa ZPUE/2/2007 z dnia 18 grudnia 2007 r. dotyczącej mianowania szefa zespołu UE ds. planowania (ZPUE dla Kosowa), 2007/888/WPZiB, Dz. Urz. L 346 / 29 z 29.12.2007 r.

${ }^{40}$ Tak szybki tryb przyjęcia dokumentu stał się możliwy dzięki interpretacji przez unijnych prawników artykułu 10 Rezolucji nr 1244 Rady Bezpieczeństwa ONZ z 1999 roku. Pomimo faktu, że Rezolucja potwierdza suwerenność Federalnej Republiki Jugosławii, a przez to jej prawnej sukcesorki, Serbii nad obszarem Kosowa, to artykuł 10 Rezolucji uprawnia Sekretarza Generalnego ONZ, aby przy pomocy „odpowiednich or- 
nych założeń misji, Unia miała wysłać do Kosowa 1800 policjantów oraz sędziów i prokuratorów. Roczny budżet misji zaplanowano na ok. 160 mln euro. Do wysłania misji potrzebna była jeszcze oficjalna decyzja Rady Ministrów UE o wprowadzeniu w życie tzw. Planu Operacyjnego.

Przyjęcie przez UE dokumentu o wysłaniu misji do Kosowa już następnego dnia po zakończeniu wyborów prezydenckich w Serbii spotkało się z ostrą reakcją władz serbskich i rosyjskich. Zoran Lončar, minister oświaty w rządzie Vojislava Koštunicy, stwierdził, że jeżeli Serbia podpisałaby zaproponowane przez Unię 28 stycznia $2008 \mathrm{r}$. Porozumienie Polityczne, będące wstępem do ostatecznego podpisania Porozumienia o Stabilizacji i Stowarzyszeniu (SAA), to faktycznie oznaczałoby to uznanie niepodległości Kosowa ${ }^{41}$.

5 lutego 2008 r. do tej decyzji UE odniósł się premier V. Koštunica. Jego zdaniem, przyjęcie dokumentu o zasadach wysłania misji cywilno-wojskowej jest sygnałem, „że bardzo szybko albańscy separatyści ogłoszą jednostronną niepodległość Kosowa"42. Zdaniem szefa serbskiego gabinetu, Unia „w bezpośredni sposób zagroziła suwerenności, integralności terytorialnej i porządkowi konstytucyjnemu Serbii”43. Przyjęcie w Brukseli dokumentu o zasadach działania misji EULEX w Kosowie skrytykowały także władze Rosji ${ }^{44}$.

17 lutego 2008 roku proklamowana została niepodległość Kosowa. Następnego dnia ministrowie spraw zagranicznych państw członkowskich UE spotkali się w nadziei na uzgodnienie wspólnego stanowiska wobec tego faktu. Istniały silne podziały co do uznania nowopowstałego państwa. Oczekiwano, że największe państwa UE - Francja, Niemcy, Wielka Brytania, Włochy, ogłoszą deklaracje o uznaniu bezpośrednio po posiedzeniu Rady45. Przynajmniej sześć innych państw - Bułgaria, Cypr, Grecja, Hiszpania ${ }^{46}$, Rumunia, Słowacja - stało na sta-

ganizacji międzynarodowych powołał międzynarodową obecność cywilną w prowincji”.

${ }^{41}$ Ibidem.

${ }^{42}$ Ibidem.

43 Ibidem.

44 Ibidem.

45 O pierwszych reakcjach na deklarację: France, Germany and UK to Recognize Kosowo, http://www.spiegel.de; World Reaction Split on Kosovo Independence, http://www.spiegel.de, 10.02.2010.

${ }^{46}$ W Hiszpanii np. niepokój budziła kwestia Basków, zwłaszcza tego, że mogliby podążyć drogą Kosowarów. Obawiano się, że jeśli konflikt zaostrzyłby się, wspólnota międzynarodowa mogłaby uznać niepodległość, by go zakończyć. Baskowie wydali oświadczenie, w którym stwierdzili, iż „Kosowo stanowi nowy przykład prawa do 
nowisku, że nie można zaakceptować jednostronnej decyzji Kosowa o oderwaniu się od Serbii. Posunięcie ogłoszone przez premiera Kosowa, Hashima Thaçi, zostało od razu uznane za nielegalne przez Serbię, która podnosiła obawy przed powtórzeniem się aktów przemocy znanych z okresu rozpadu Jugosławii. Miało to wymusić na przedstawicielach państw członkowskich zasiadających w Radzie przyjęcie takich środków, jakie będą w stanie zapewnić stabilność w regionie.

D. Reljic wskazywał, że trzy państwa Rady Bezpieczeństwa ONZ Francja, Stany Zjednoczone i Wielka Brytania - stały na stanowisku, że rezolucja Rady Bezpieczeństwa ONZ nr 1244, w której zagwarantowana została integralność terytorialna Serbii, nadal obowiązuje ${ }^{47}$. Rosja i Chińska Republika Ludowa to kwestionowały, a większość niestałych członków Rady była podobnego zdania ${ }^{48}$.

M. Tosic twierdzil, że decyzja państw popierających niepodległość Kosowa nie tylko otwarcie sprzeciwiała się Karcie Narodów Zjednoczonych, która odwołuje się do integralności terytorialnej państw członkowskich, a także rezolucji Rady Bezpieczeństwa nr 1244, zawierającej zapis o Kosowie jako integralnej części Serbii, ale także uczyniła niemożliwą jakąkolwiek reakcję RB ONZ na ten jednostronny krok ${ }^{49}$.

Brak spójności Unii Europejskiej wobec Kosowa mógł, zdaniem komentatorów, zagrozić próbom budowania jednolitej polityki zagranicznej. Wykazał, że istnieje pluralizm postaw, że UE nie jest homogenicznym blokiem. Dodawano przy tym, że nikt nie oczekiwał od Unii działania w charakterze państwa, ponieważ nie jest nim ona ${ }^{50}$.

Po wielogodzinnej dyskusji o tym, jak zareagować na kosowską deklarację niepodległości, ministrowie spraw zagranicznych państw UE byli w nastroju samozadowolenia ${ }^{51}$. Lektura tekstu przygotowanego przez nich sprawiała inne wrażenie. Znalazł się w nim jedynie zapis, iż każde z państw indywidualnie, w zgodzie z własną praktyką i prawem

samostanowienia”.

${ }_{47}$ Zarówno Stany Zjednoczone, jak i Australia, szybko uznały jednak Kosowo.

48 'Kosovo Is not Independent, It Is an EU Protectorate', Interview with Balkans Expert Dusan Reljic, http://www.spiegel.de, 10.02.2010.

${ }^{49} \mathrm{M}$. Tosic, Kosovan consequences, http://www.guardian.co.uk, 10.02.2010.

${ }^{50}$ Kosovo Is not Independent..., op. cit.

${ }^{51}$ Minister spraw zagranicznych Niemiec, Frank-Walter Steinmeier, nazwał przygotowane oświadczenie „sukcesem Europy”. Jego słoweński odpowiednik, Dimitrij Rupel, stwierdził, iż „Unia Europejska raz jeszcze przetrwała test jedności”. Francuski minister spraw zagranicznych, Bernard Kouchner, komentował: „To koniec bardzo długiego kryzysu i okresu wielkiego napięcia w tym regionie świata”. 
międzynarodowym, zdecyduje o kształcie swych relacji z Kosowem ${ }^{52}$.

Unia Europejska stanęła w obliczu podziału nie do przezwyciężenia ${ }^{53}$. Większość państw, tj. 17 z 27, opowiadała się za uznaniem. Duża część państw europejskich była temu jednak przeciwna lub wahała się. Ścierające się w Europie wizje, jak odnieść się do kwestii kosowskiej, odzwierciedlały także tendencje panujące na świecie ${ }^{54}$. Kreowano wrażenie, że Unia Europejska bliska jest osiągnięcia jednolitego stanowiska wobec kwestii kosowskiej. Z nielicznymi wyjątkami, odmalowywano obraz zgody co do tego, jak poradzić sobie z tak istotnym problemem w bliskim sąsiedztwie. Rozwiązanie okazało się „typowo brukselskie" - każde państwo powinno czynić, co uznaje za słuszne ${ }^{55}$.

Oczekiwano, że 18 lutego, podczas posiedzenia unijnych ministrów spraw zagranicznych zapadnie decyzja o wyjeździe i ustaleniu terminu rozpoczęcia misji. Sprzeciw wobec misji UE w Kosowie wyrażały władze Serbii, które uważały ją za krok ku uznaniu niepodległości Kosowa. Trwały również spekulacje, czy Cypr, który obawia się podobnego precedensu w przypadku uznawanej jedynie przez Turcję Republiki Cypru Północnego, nie wycofa swej zgody na misję po uznaniu Kosowa przez grupę największych państw UE. Serbski premier V. Koštunica oświadczył 9 lutego, że Kosowo nie ma ceny, a władze serbskie nie chcą żadnych rekompensat od Zachodu w zamian za zaakceptowanie niepodległości prowincji. Serbski premier powiedział w wywiadzie dla jednej z agencji prasowych: „Decyzją o wysłaniu misji EULEX w celu spowodowania jednostronnego proklamowania niepodległości przez Kosowo, Unia Europejska dokonała zbrodni nad Rezolucją nr 1244 Rady Bezpieczeństwa ONZ, jasno gwarantującą poszanowanie integralności terytorialneji całości Serbii” ${ }^{6}$. Dodał, że w ten sposób UE „w najpoważniejszy sposób pogwałciła Kartę Narodów Zjednoczonych i przekroiła uznane międzynarodowo granice Serbii" ${ }^{57}$. Według szefa rządu, unijnym decydentom najbardziej odpowiadałaby sytuacja, w której Serbia, w obliczu podpisania proponowanego przez UE tzw. przejściowego porozumienia politycznego, co stanowi w isto-

${ }^{52}$ Ibidem.

${ }^{53}$ Patrz, np.: M. Tran, J. Orr, US and EU powers to recognise Kosovan statehood, http://guardian.co.uk; I. Traynor, Spain exposes EU split as US leads recognition, http://www.guardian.co.uk, 10.02.2010.

${ }^{54}$ H. J. Schlamp, op. cit.

55 Ibidem.

${ }^{56}$ Ł. Kobeszko, Serbia-Kosowo/Belgrad nie chce rekompensaty za niepodległość Kosowa, http://www.psz.pl, 10.02.2010.

${ }^{57}$ Ibidem. 
cie wstęp do podpisania Porozumienia o Stabilizacji i Stowarzyszeniu (SAA), udzieliła zgody „na największy gwałt prawny, który czyni się nad pojedynczym krajem od czasu utworzenia ONZ, która przecież wszystkim swoim członkom gwarantuje nienaruszalność istniejących granic. Serbia takiej zgody nigdy nie da" ${ }^{8}$. Premier ocenił, że w kwestii Kosowa Unia Europejska znajduje się pod znacznym naciskiem ze strony USA i przyjęcie dyktowanych warunków odznaczać będzie zniszczenie zasad stanowiących fundament Starego Kontynentu ${ }^{59}$. Podobne stanowisko wyraził prezydent Boris Tadić, który zapowiedział, że Serbia nigdy nie uzna niepodległości Kosowa, a jednostronne jej proklamowanie może doprowadzić do nieprzewidywalnych następstw na całych Bałkanach i w różnych częściach świata. Prezydent oczekiwał również, że stanowisko Serbii w kwestii Kosowa poprą rządy wszystkich sąsiednich państw postjugosłowiańskich oraz bałkańskich. Opowiedział się jednocześnie za powrotem do stołu rozmów z kosowskimi Albańczykami. Wyjawił także, że o poparciu serbskiego stanowiska w sprawie Kosowa zapewniły go władze Indii, a niektórzy liderzy państw europejskich oświadczyli mu, że nigdy nie uznają oficjalnie niepodległego Kosowa.Problem stanowiła niepewność co do uznania podstaw prawnych EULEX ${ }^{60}$. Część państw rozważała przyłączenie się do Hiszpanii w nieuczestniczeniu w tej misji, dopóki jej legitymacja nie będzie jasna ${ }^{61}$. Określając misję jako „dużą pomyłkę ze strony Unii Europejskiej”, ambasador Rosji przy UE, Władymir Czyżkow, oświadczył jednocześnie na konferencji prasowej 18 kwietnia 2008 r., iż jest ona nielegalna i odsunął nadzieję, że może ona uzyskać legitymację w momencie, gdy Sekretarz Generalny ONZ, Ban Ki-Moon, przeniesie na nią kompetencje z UNMIK. W. Czyżkow stwierdził, że Sekretarz Generalny nie ma takich kompetencji, o czym zresztą toczyły się kilka dni wcześniej rozmowy. Ambasador ostrzegł także przed wszelkimi

\footnotetext{
${ }^{58}$ Ibidem.

${ }^{59}$ Ibidem.

${ }^{60} \mathrm{O}$ dylematach związanych z misją EULEX m.in.: I. Traynor, Questions remain over EU's role, http://www.guardian.co.uk, 10.02.2010.

${ }^{61}$ Władze Hiszpanii zdecydowały się nie wyrazić zgody na uczestnictwo swego personelu w unijnej misji dopóki UNMIK nie przekaże EULEX własnej jurysdykcji. W kuluarach mówiono, że kilka państw może pójść w ślad Hiszpanii i ogłosić podobne w treści deklaracje, zmierzające do zabezpieczenia się przed precedensem. Źródła w Radzie Unii Europejskiej donosiły, że nie mają takich informacji, natomiast część ministrów miała sygnalizować potencjalne problemy z dostarczeniem kontyngentów na czas. Władze Słowenii i obejmującej po niej przewodnictwo Francji wezwały Serbię do niesprzeciwiania się przyjęciu EULEX, jeśli państwo to chce kontynuować dialog przedakcesyjny.
} 
próbami rozmieszczania sił EULEX w Kosowie przed ustanowieniem na jego terytorium międzynarodowej obecności militarnej ${ }^{62}$.

Serbia stanowczo sprzeciwiała się misji EULEX i zapowiadała współpracę jedynie z UNMIK, której mandat zakładał poszanowanie integralności terytorialnej tego państwa. Stanowisko Serbii uległo dalszemu usztywnieniu po ogłoszeniu 17 lutego niepodległości Kosowa. Nie było to jednak jedyne zagrożenie. Komisja Europejska widziała EULEX jako narzędzie oparte na rezolucji Rady Bezpieczeństwa ONZ nr $1244^{63}$. Postanowienie to było jednak później dyskretnie modyfikowane. Na oficjalnej stronie Zespołu Planowania UE ds. Kosowa pojawiły się informacje, iż EULEX nie zastąpi UNMIK ${ }^{64}$.

Ministrowie spraw zagranicznych Unii Europejskiej i prezydent Serbii, B. Tadić, podpisali długo odwlekany układ przedakcesyjny ${ }^{6}$. Premier V. Koštunica ogłosił natychmiast, że akt ten jest nielegalny i stwierdził, iż powołany po wyborach rząd doprowadzi do jego anulowania $^{66}$. Porozumienie stało się kluczowym elementem serbskiej kampanii wyborczej w momencie, w którym sondaże wskazywały na wyrównane poparcie dla obozów nacjonalistycznego i proeuropejskiego. B. Tadić zauważył, że układ niesie jasne przesłanie - „Przyszłość Ser-

${ }^{62}$ EU Kosovo mission up in the air, 18.04.2008, http://www.euractiv.com, 10.02.2010.

${ }^{6} 3$ Jedynym fragmentem dającym możliwość takiej interpretacji, był ten mówiący o uprawnieniu Sekretarza Generalnego ONZ do ustanowienia w Kosowie międzynarodowej obecności cywilnej. Dyplomaci wskazywali, że państwa zachodnie oczekiwały od Sekretarza Generalnego wykorzystania tego zapisu dla zapewnienia legitymacji misji EULEX. Ten oświadczył jednak, że UNMIK winna kontynuować administrowanie Kosowem, zależnie od dalszych instrukcji ze strony Rady Bezpieczeństwa ONZ. Tymczasem artykuł 5 decyzji Rady o powołaniu EULEX stanowi, że „faza operacyjna EULEX rozpocznie się wraz z przekazaniem władzy przez Misję Narodów Zjednoczonych w Kosowie, UNMIK".

${ }^{64}$ Rada tłumaczyła ten fakt „odmiennymi filozofiami”, jakimi kierują się obie misje. Potwierdzono, że UNMIK winna wypełniać swe zadanie aż do uzgodnionego momentu wycofania.

${ }^{65}$ Podpisanie układu stało się możliwe po tym, jak ministrowie Belgii i Danii odstąpili od warunku wstępnego - uzależnienia podpisania układu czy przyznania jakichkolwiek koncesji Serbii dopiero w momencie, gdy ta zacznie w pełni współpracować z Międzynarodowym Trybunałem do spraw byłej Jugosławii.

${ }^{66}$ Kwestia kosowska stanowiła przedmiot zaniepokojenia V. Koštunicy, który podpisanie SAA „aktem antypaństwowym i antykonstytucyjnym”. Serbski minister spraw zagranicznych, Vuk Jeremić, oświadczył, że podpisanie układu było momentem przełomowym dla Serbii, jak i dla Unii Europejskiej. Powiedział na konferencji prasowej: „Wierzymy, że jesteśmy na nieodwracalnej drodze do członkostwa w Unii Europejskiej”. Przewodniczący Serbskiej Partii Radykalnej, Dragan Todorović, porównał natomiast podpisanie SAA do podpisania paktu z państwami osi w trakcie II wojny światowej. 
bii leży w Europie”. Wyraził życzenie, by Serbia została do końca roku uznana za państwo kandydujące. Wyjaśnił jednocześnie, że podpisanie układu, który ma charakter ekonomiczny, nie jest równoznaczne z uznaniem przez Serbię niepodległości Kosowa.

\section{DALSZE KONSEKWENCJE}

M. Tosic stwierdzil, powołując się na I. Bancrofta, że uznanie Kosowa stworzy dwa niepokojące precedensy. Po pierwsze, dla dokonywania secesji w kolejnych państwach, po drugie, dla tworzenia nowych państw w oparciu o interwencje militarne, jak było w przypadku NATO i UE w Kosowie ${ }^{67}$. W analizach wskazywano, że Kosowo może stać się swoistym „ogniskiem zapalnym”, z którym trudno będzie sobie porazić. Mitrovicę, będącą sceną aktów przemocy, traktowano jako potencjalne zarzewie przyszłego konfliktu. Strona serbska postrzegała rosyjskich żołnierzy stacjonujących w północnym Kosowie jako siły pokojowe ${ }^{68}$.

Podkreślano, że Kosowo spowodowało nowy rozłam wśród państw Europy. Niemcy, Wielka Brytania, Włochy dokonały szybko uznania. Bułgaria, Cypr, Grecja, Hiszpania, Słowenia sprzeciwiały się temu. W państwach wielonarodowych i multikulturowych istniało przekonanie, iż niepodległość Kosowa ożywi dążenia separatystyczne Basków w Hiszpanii czy Węgrów w Rumunii ${ }^{69}$.

Rosyjski minister spraw zagranicznych Siergiej Ławrow określił niepodległość Kosowa mianem „początku końca Europy”. Strona rosyjska utrzymywała, że przyczyni się ona do ponownego zaostrzenia sytuacji na obszarach objętych „zamrożonymi konfliktami”, jak Abchazja, Osetia Południowa ${ }^{70}$, Naddniestrze. Wykazywała także, iż kwestia Kosowa może stać się precedensem ${ }^{71}$. Stanowisko państw zachodnich mogło wydawać się niespójne, a nawet wewnętrznie sprzeczne. Niewielu wierzyło, iż Kosowo będzie autentycznie wolne. Twierdzono

${ }^{67}$ M. Tosic, op. cit.

${ }^{68}$ A. N. Roy, Is Kosovo the End of Europe?, http://www.mainstreamweekly.net, 10.02.2010.

${ }^{69}$ Ibidem.

${ }^{70} \mathrm{~W} 1992$ roku ogłoszona została niepodległość Osetii Południowej. Utrzymywano wówczas, że tylko dzięki obecności żołnierzy rosyjskich udało się zapobiec poważniejszemu konfliktowi. Strona rosyjska zaczęła rozważać uznanie tego państwa.

${ }^{71}$ A. N. Roy, op. cit. 
nawet, iż stanie się ono „protektoratem Unii”72. Próby angażowania się w sytuację na Bałkanach po raz kolejny miały okazać się ryzykowne ${ }^{73}$.

D. Korski argumentował, iż kwestię kosowską można postrzegać jako okazję do rozwinięcia Wspólnej Polityki Zagranicznej i Bezpieczeństwa oraz mechanizmów interwencji już funkcjonujących w Bośni i Hercegowinie oraz Macedonii. Niemniej, istniało ryzyko, że podjęte kroki będą kontrproduktywne wobec zakładanych celów, dojdzie do nowych podziałów w samej Unii, która osłabi tym własną wiarygodnośćc ${ }^{74}$.

Obawiano się, iż na samych Bałkanach uznanie Kosowa doprowadzi do legitymizacji podobnych kroków w państwach, które pod presją unijną przechodzily procesy pokojowe. Znaczące, homogeniczne terytorialnie społeczności w Bośni (Serbowie i Chorwaci), a także w Macedonii (Albańczycy) wyrażały stanowisko, iż uznanie Kosowa przez Stany Zjednoczone i Unię Europejską będzie dla nich „zielonym światłem" dla osiągnięcia własnych celów ${ }^{75}$. Mówiono także o tym, że uznanie Kosowa w jakiejkolwiek formie przez Unię Europejską sprawi, zniweczy przemiany, jakie dokonują się w Serbii od 2000 roku, radykalnie zmieni postrzeganie w tym państwie samej Unii, a przy tym uczyni niemal niemożliwe kontynuowanie drogi do akcesji do UE i NATO ${ }^{76}$.

Serbskie reakcje bezpośrednio po ogłoszeniu niepodległości, zwłaszcza wypowiedzi premiera V. Koštunicy, wskazywały, że Serbia nie zamierza łatwo zrezygnować z terytorium, które uznaje za własne ${ }^{77}$. Serbski premier wezwał nawet Sekretarza Generalnego ONZ Ban KiMoona do zakończenia polityki „nagiej przemocy i naruszania sprawiedliwości” wobec Serbii ${ }^{78}$. Stwierdził także, iż „Unia Europejska musi uznać Serbię całą z niepodzielnym Kosowem"79. O planach wysłania przez UE misji do Kosowa mówił natomiast, iż stanowiłoby to naruszenie serbskiej suwerenności ${ }^{80}$.

Miesiąc po ogłoszeniu niepodległości Kosowo uznały Bułgaria, Chorwacja i Węgry. Strona bułgarska uczyniła to dokładnie dzień póź-

${ }^{72} \mathrm{O}$ roli UE także m.in.: I. Traynor, Questions remain over EU's role, http://www. guardian.co.uk, 10.02.2010.

${ }^{73}$ A. N. Roy, op. cit.

${ }^{74}$ M. Tosic, op. cit.

${ }^{75}$ Ibidem.

${ }^{76}$ Ibidem.

${ }_{77}$ Patrz m.in: Flags are not enough, http://www.guardian.co.uk, 10.02.2010.

${ }^{78}$ Serbia Divided on Approach to EU, http://www.spiegel.de, 10.02.2010.

${ }^{79}$ Ibidem.

${ }^{80}$ Ibidem. 
niej od dwóch pozostałych, tj. 20 marca. Władze wszystkich trzech państw zastrzegły, iż „Kosowo winno dostarczyć gwarancji państwa wieloetnicznego"81. Owo uznanie wywołało natychmiastowy protest strony serbskiej. „Każde państwo, które zdecyduje się uznać nielegalnie powstałe państwo Kosowo, narusza prawo międzynarodowe"82 stwierdził w trakcie wizyty w Atenach V. Jeremić. Wezwał on władze greckie do niepodejmowania tego $\mathrm{kroku}^{83}$.

Bezpośrednio po ogłoszeniu przez Kosowo niepodległości pojawiły się głosy o konieczności szybkiego podjęcia przez Unię działań w celu zapobieżenia negatywnym konsekwencjom społecznym, politycznym, a także z dziedziny bezpieczeństwa. Nieodzowne stało się przyjęcie całościowego podejścia regionalnego, skoncentrowanego wokół kolejnych kroków mających doprowadzić poszczególne państwa Bałkanów Zachodnich $^{84}$ do członkostwa w UE ${ }^{85}$.

Można przytaczać przykłady inicjatyw, które miały służyć odnowieniu i poprawie relacji z regionem. Pakt Stabilności dla Europy Południowo-Wschodniej od 1999 roku stymulował rozwój współpracy transgranicznej. Przyczynił się do rozwoju infrastruktury drogowej, kolejowej i wodnej, a także współpracy w zakresie zwalczania przestępczości ${ }^{86}$.

Odnowione Środkowoeuropejskie Porozumienie o Wolnym Handlu (ang. Central European Free Trade Agreement - CEFTA) zostało pomyślane jako główna siła promująca przedsiębiorczość i handel w regionie. Podobnie w przypadku Inicjatywy Współpracy Europy Południowo-Wschodniej (ang. Southeast European Cooperative. Initiative - SECI), która miała przyczynić się do lepszego przygotowania państw kandydujących i potencjalnie kandydujących do akcesji do Unii, zapewniając forum polityczne o regionalnym zasięgu, w którym uczestniczyły zarówno państwa członkowskie, jak i kandydujące ${ }^{87}$.

Doświadczenie Bułgarii i Rumunii może okazać się cenne dla rozwijania strategii akcesyjnej dla państw Bałkanów Zachodnich, których rozwój był opóźniony przez procesy odbudowy po konfliktach. Ich po-

${ }^{81}$ Balkan Nations Recognize Independent Kosowo, http://www.spiegel.com, 10.02.2010.

${ }^{82}$ Ibidem.

${ }^{83}$ Ibidem. bię.

${ }^{84}$ Albanię, Bośnię i Hercegowinę, Chorwację, Czarnogórę, Kosowo, Macedonię, Ser-

${ }^{85}$ W. Petritsch, Next step for Kosovo?, http://www.guardian.co.uk, 10.02.2010.

${ }^{86}$ Ibidem.

${ }^{87}$ Ibidem. 
trzeby winny zostać uwzględnione w nowym podejściu Unii. Zarówno $\mathrm{w}$ interesie państw regionu, jak i samej UE, leży bowiem przyspieszenie procesu integracji. Nadanie mu nowego impetu przyczyniłoby się do konsolidacji Unii, zarówno w sensie terytorialnym, jak i politycznym, a także wzmocnienia jej roli w sąsiadujących regionach - Śródziemnomorzu, Bliskim Wschodzie, Basenie Morza Czarnego ${ }^{88}$.

\section{SUMmary}

Russian Foreign Minister, Sergei Lavrov, once said that Kosovo's independence could be the beginning of the end for Europe, and that official recognition of its sovereignty would threaten global security. It was feared that Kosovo's unilateral declaration of independence, and its recognition by European countries in particular, would open up a Pandora's Box. In fact, as it is claimed in this article, Kosovo may be treated a precedent by other separatist republics and autonomous regions, which might one day demand similar recognition and the same rights that the Kosovars can now possibly enjoy.

\section{Nota O AUTORZE}

Marta Zobeniak [emzet@amu.edu.pl] - absolwentka politologii i stosunków międzynarodowych, doktorantka na Wydziale Nauk Politycznych i Dziennikarstwa UAM w Poznaniu (Zakład Najnowszej Historii Politycznej). Członkini Stowarzyszenia Ośrodek Badań i Edukacji Europejskiej w Poznaniu. Jej zainteresowania naukowe koncentrują się w obrębie polityki międzynarodowej i współczesnych stosunków międzynarodowych, ze szczególnym uwzględnieniem problematyki europejskiej.

${ }^{88}$ Ibidem. 